\title{
Survival analysis of patients with locally advanced non-small cell lung cancer treated at the Nu-Med Radiotherapy Center in Elbląg
}

\author{
Marcin Kurowicki ${ }^{1}$, Karolina Osowiecka², Sergiusz Nawrocki ${ }^{3}$, Łukasz Cieśliński ${ }^{1}$, \\ Barbara Szostakiewicz ${ }^{1}$, Andrzej Badzio ${ }^{4}$
}

'Nu-Med Radiotherapy Center, Elblag, Poland

2Department of Psychology and Sociology of Health and Public Health, School of Public Health, University of Warmia and Mazury in Olsztyn, Poland Department of Public Health, Medical University of Warsaw, Poland

${ }^{3}$ Department of Oncology, Faculty of Medical Sciences, Collegium Medicum, University of Warmia and Mazury in Olsztyn, Poland

${ }^{4}$ Department of Oncology and Radiotherapy, Medical University of Gdansk, Poland

Introduction. The study aimed to report the efficiency of radical radiotherapy and chemoradiotherapy in patients with non-small cell lung cancer (NSCLC) treated in the Nu-Med Radiotherapy Center in Elbląg.

Material and methods. Ninety-two patients diagnosed with NSCLC treated between 2013 and 2016 were included in the analysis. Overall survival (OS) was estimated by the Kaplan-Meier method.

Results. The 2-year OS for all patients was 36\% (median 1.5 years). Two prognostic factors had a significant impact: treatment method and performance status (PS). Patients who underwent concurrent radiochemotherapy and were treated sequentially had a better 2-year OS in comparison with those treated with radiotherapy alone (respectively $46 \%$ and $37 \%$ vs. $25 \%, \mathrm{p} \leq$ 0.05). Patients with PS $0-1$ had better OS (median 1.6 years) compared with PS 2 (median 0.7 years, $p=0.04$ ). Other prognostic factors analysed had no impact on OS in our study.

Conclusions. The treatment results of our patients are comparable to those in published trials and meta-analyses.

Key words: non-small cell lung cancer, chemoradiotherapy, radiotherapy, overall survival

\section{Introduction}

In 2013, of more than 12.7 million malignancies diagnosed worldwide, about 13\% (1.6 million) were lung malignancies. In Poland, lung cancer is the most common type of cancer in men, and among women it ranks third. It's also the prime cause of death from malignancy for both sexes [1]. Cigarette smoking is the leading cause of lung cancer development. Smoking increases its risk 20-30 fold [2, 3]. The treatment method of patients diagnosed with lung cancer depends mainly on the clinical stage of the disease and patient comorbidities. One of the reasons for the poor prognosis is late diagnosis, and therefore most patients are disqualified from radical surgery [4]. According to EUROCARE 5 (EUROpean CAncer REgistry based study on the survival and care of cancer patients), the 5 -year relative survival of lung cancer patients diagnosed between 2000 and 2007 was 14.3\% for Poland, and the European average was $12.6 \%$ [5]. The most frequent histology of lung cancer is non-small cell lung cancer (NSCLC) [6]. The 5-year overall survival of patients diagnosed with NSCLC depending on clinical stage ranges 4-66\% [7]. For patients with early-stage

\section{How to cite:}

Kurowicki M, Osowiecka K, Nawrocki S, Cieśliński Ł, Szostakiewicz B, Badzio A. Survival analysis of patients with locally advanced non-small cell lung cancer treated at the Nu-Med Radiotherapy Center in Elbląg. NOWOTWORY J Oncol 2020; 70: 135-143. 
NSCLC surgery remains the primary treatment; for locally advanced non-small cell lung cancer chemoradiotherapy is the treatment of choice. However, the effectiveness of the latter leaves much to be desired. We have particularly high hopes for the addition of immunotherapy to chemoradiotherapy, which has significantly improved survival in inoperable patients [8].

However, there are some limitations to the data supporting treatment strategies in specific patient subsets and studies have included heterogeneous patient populations. The definition of clinical stage III has changed over time, and early reviews have often been inadequately powered to detect small differences in survival outcome, have not been randomised or have had limited time of follow-up. Development in therapy: the use of more active chemotherapy agents and refinements in radiation and surgical techniques also limit the interpretation of earlier clinical trials [9]. The aim of this study was to analyse and report the outcome of the treatment of non-small cell lung cancer patients with radical radiotherapy and chemoradiotherapy in our department.

\section{Material and methods}

A list of patients was generated from the institutional database, Mosaiq and Clininet systems. The medical records of all patients were available for this study. The research was conducted on a group of 109 patients with primary, unresectable, non-metastatic cancers, with a histopathological diagnosis of non-small cell lung cancer, who underwent curative radio- and radiochemotherapy between 2013 and 2016 in the Nu-Med Radiotherapy Center in Elbląg. Seventeen patients were excluded from the analysis. The reason for exclusion was resection in 11 patients (10\%), including nine patients treated with postoperative radiation and two patients treated with preoperative radiochemotherapy. Six patients (6\%) who underwent therapy because of recurrence were also excluded from the analysis. All patients were staged with computed tomography of the chest and abdominal ultrasound, 57 (62\%) had PET examinations, 87 (95\%) had a spirometric evaluation.

The stage was determined by the UICCTNM classification of Malignant Tumours $-7^{\text {th }}$ edition. A total dose of $66 \mathrm{~Gy}$ with fraction dose 2 Gy was administrated in 55 patients, 66 Gy (fraction dose $2.2 \mathrm{~Gy}$ ) in 8 patients, $60 \mathrm{~Gy}$ (fraction dose $2 \mathrm{~Gy}$ ) in 27 cases and 50 Gy in 2 patients. Dose 60 Gy was prescribed for concomitant treatment, 66 Gy for the sequential scheme or for radiotherapy alone. The dose of $50 \mathrm{~Gy}$ was prescribed for tumours infiltrating vertebral bodies close to the spine. The CTV included lung tumour and pathological lymph nodes with $8 \mathrm{~mm}$ margins. In post-chemotherapy cases, the CTV consisted of residual lung tumour and lymph nodes with an $8 \mathrm{~mm}$ margin and initially involved mediastinal node groups. In both scenarios, the PTV was created by adding $7 \mathrm{~mm}$ margins radially and $10 \mathrm{~mm}$ in the craniocaudal direction.

Treatment plans were prepared using Prowess or Eclipse software. Radiotherapy was delivered with Artiste (Siemens)
Liniacs, using photons X $6 \mathrm{MV}$, with IMRT in 79 patients (86\%) and $3 \mathrm{D}$ technique in 13 (14\%). The method was chosen by attending a radiation oncologist, after DVH comparison.

Patients treated with chemoradiotherapy received different chemotherapy regimens: carboplatin-vinorelbine (KN) (6 patients), cisplatin-vinorelbine (PN) (47 patients), carboplatin-etoposide (KE) (1 patient), cisplatin-etoposide (PE) (6 patients), cisplatin (1 patient), cisplatin-pemetrexed (1 patient), KN+PN (1 patient), KN+PXL/CDDP (1 patient). The induction chemotherapy regimen was chosen and administered by medical oncologists from other hospitals.

The efficacy of radiotherapy and chemoradiotherapy was estimated by survival analysis from the date of the beginning of the treatment to the last follow-up visit/death. Variables that can impact patient survival (sex, age, BMI, place of residence, the distance between the place of residence and Nu-Med Center, baseline WHO PS, clinical stage, lymph node status, tumour localisation, type of histopathology, type of treatment) were analysed.

The proportion between subgroups: radiotherapy alone $v s$. sequential radiochemotherapy $v$ s. concurrent radiochemotherapy in different factors were compared using the $\mathrm{chi}^{2}$ test. Overall survival (OS) was estimated by the Kaplan-Meier method and differences in survival were compared by the log-rank test. Uni- and multivariable analysis was estimated through the Cox regression model. Univariate variables with $p<0.25$ were included in the multivariable analysis. A p-value $<0.05$ was considered to be significant. The analysis was performed using TIBCO Software Inc. (2017) and Statistica (a data analysis software system), version 13. http://statistica.io.

\section{Results}

Ninety-two patients were included in the analysis. The majority of patients were men $(72 ; 78 \%)$ and lived in cities $\leq 100$ thousand $(44 ; 48 \%)$ and villages $(31 ; 34 \%)$. The median age was 64 years. Half of the patients $(47 ; 51 \%)$ were of PS (performance status) grade 0 according to the WHO/ECOG scale during the first visit. Most patients were treated in clinical stage IIIA (53; $58 \%)$ and IIIB (31; 34\%), with T3-4 (70\%), with N2-3 (80\%), with squamous cell carcinoma $(68 ; 74 \%)$ and adenocarcinoma (19; $21 \%)$, tumour localisation on right side (59; 64\%). Over half (57; 62\%) had a PET examination before treatment. 28 patients (30\%) underwent radiotherapy only, 38 patients (41.5\%) had sequential radiochemotherapy and 26 patients (28.5\%) had concurrent radiochemotherapy. Most patients (58; 63\%) were referred from Szpital Specjalistyczny in Prabuty (the regional pulmonological center) for treatment to the Nu-Med Center and the 34 remaining patients (37\%) where diagnosed in hospitals in Elbląg (tab. I).

More patients who received radiotherapy alone were $>64$ years compared with patients who underwent sequential or concurrent radiochemotherapy, respectively $89 \%$ vs. $32 \%$ vs. $23 \%(p<0.001)$. There was a significant difference in perfor- 
Table I. Characteristics of patients

\begin{tabular}{|c|c|c|c|c|c|c|c|c|c|c|}
\hline \multirow[t]{2}{*}{ Patient's characteristic } & & \multicolumn{2}{|c|}{ All } & \multicolumn{2}{|c|}{$\begin{array}{l}\text { Radiotherapy } \\
\text { alone }\end{array}$} & \multicolumn{2}{|c|}{$\begin{array}{l}\text { Sequential radio- } \\
\text { chemotherapy }\end{array}$} & \multicolumn{2}{|c|}{$\begin{array}{l}\text { Concurrent radio- } \\
\text { chemotherapy }\end{array}$} & \multirow{2}{*}{$\begin{array}{c}\mathrm{Chi}^{2} \\
\text { test }\end{array}$} \\
\hline & & $\mathrm{N}$ & $\%$ & $\mathbf{N}$ & $\%$ & $\mathrm{~N}$ & $\%$ & $\mathrm{~N}$ & $\%$ & \\
\hline & & 92 & 100 & 28 & 30 & 38 & 41.5 & 26 & 28.5 & \\
\hline \multirow[t]{3}{*}{ Age (start of radiotherapy) } & \multicolumn{10}{|c|}{ range: $46-82$ years; median: 64 years } \\
\hline & $\leq 64$ & 49 & 53 & 3 & 11 & 26 & 68 & 20 & 77 & \multirow{2}{*}{$<0.001$} \\
\hline & $>64$ & 43 & 47 & 25 & 89 & 12 & 32 & 6 & 23 & \\
\hline \multicolumn{11}{|l|}{ Sex } \\
\hline & women & 20 & 22 & 5 & 18 & 9 & 24 & 6 & 23 & \multirow{2}{*}{0.84} \\
\hline & men & 72 & 78 & 23 & 82 & 29 & 76 & 20 & 77 & \\
\hline \multirow[t]{4}{*}{ BMI } & \multicolumn{10}{|c|}{ range: $15.8-46.1$; median 26} \\
\hline & $\leq 26$ & 42 & 46 & 15 & 53.5 & 18 & 47 & 9 & 34.5 & \multirow{3}{*}{0.46} \\
\hline & $>26$ & 42 & 46 & 12 & 43 & 16 & 42 & 14 & 54 & \\
\hline & no data & 8 & 9 & 1 & 3.5 & 4 & 11 & 3 & 11.5 & \\
\hline \multicolumn{11}{|l|}{ Place of residence } \\
\hline & village & 31 & 34 & 9 & 32 & 13 & 34 & 9 & 34.5 & \multirow{3}{*}{0.08} \\
\hline & cities $\leq 100$ thous & 44 & 48 & 14 & 50 & 22 & 58 & 8 & 31 & \\
\hline & cities $>100$ thous & 17 & 18 & 5 & 18 & 3 & 8 & 9 & 34.5 & \\
\hline \multirow{3}{*}{$\begin{array}{l}\text { Distance from place of } \\
\text { residence to Nu-Med. Center }\end{array}$} & \multicolumn{10}{|c|}{ range: 0-616 km; median $67 \mathrm{~km}$} \\
\hline & $\leq 67$ & 47 & 51 & 13 & 46 & 17 & 45 & 17 & 65 & \multirow{2}{*}{0.22} \\
\hline & $>67$ & 45 & 49 & 15 & 54 & 21 & 55 & 9 & 35 & \\
\hline \multicolumn{11}{|c|}{ Performance status according WHO/ECOG during first visit } \\
\hline & 0 & 47 & 51 & 10 & 36 & 17 & 45 & 20 & 77 & \multirow{3}{*}{0.02} \\
\hline & 1 & 37 & 40 & 14 & 50 & 17 & 45 & 6 & 23 & \\
\hline & 2 & 8 & 9 & 4 & 14 & 4 & 10 & 0 & 0 & \\
\hline Clinical stage & & & & & & & & & & \\
\hline & $\mathrm{IB}$ & 3 & 3 & 3 & 11 & 0 & 0 & 0 & 0 & \\
\hline & $\| \mathrm{A}$ & 2 & 2 & 2 & 7 & 0 & 0 & 0 & 0 & \\
\hline & $\| B$ & 3 & 3 & 2 & 7 & 1 & 3 & 0 & 0 & 0.02 \\
\hline & $\| \mathrm{A}$ & 53 & 58 & 16 & 57 & 19 & 50 & 18 & 69 & \\
\hline & $\||| B$ & 31 & 34 & 5 & 18 & 18 & 47 & 8 & 31 & \\
\hline Lymph nodes status & & & & & & & & & & \\
\hline & $\mathrm{N}+$ & 79 & 86 & 20 & 71 & 35 & 92 & 24 & 92 & \\
\hline & N- & 13 & 14 & 8 & 29 & 3 & 8 & 2 & 8 & 0.05 \\
\hline Tumor localization & & & & & & & & & & \\
\hline & right & 59 & 64 & 17 & 61 & 26 & 68 & 16 & 61 & $07^{*}$ \\
\hline & left & 29 & 32 & 9 & 32 & 12 & 32 & 8 & 31 & \\
\hline & mediastinum & 3 & 3 & 2 & 7 & 0 & 0 & 1 & 4 & \\
\hline & right and left & 1 & 1 & 0 & 0 & 0 & 0 & 1 & 4 & \\
\hline Type of histopathology & & & & & & & & & & \\
\hline & planoepitheliale & 68 & 74 & 19 & 68 & 30 & 79 & 19 & 73 & 0744 \\
\hline & adenocarcinoma & 19 & 21 & 7 & 25 & 7 & 18 & 5 & 19 & 0.147 \\
\hline & undetermined & 5 & 5 & 2 & 7 & 1 & 3 & 2 & 8 & \\
\hline PET & & & & & & & & & & \\
\hline & yes & 57 & 62 & 21 & 75 & 14 & 37 & 22 & 85 & 01 \\
\hline & no & 35 & 38 & 7 & 25 & 24 & 63 & 4 & 15 & $=0.001$ \\
\hline
\end{tabular}




\begin{tabular}{|c|c|c|c|c|c|c|c|c|c|c|}
\hline \multirow[t]{2}{*}{ Patient's characteristic } & & \multicolumn{2}{|c|}{ All } & \multicolumn{2}{|c|}{$\begin{array}{l}\text { Radiotherapy } \\
\text { alone }\end{array}$} & \multicolumn{2}{|c|}{$\begin{array}{l}\text { Sequential radio- } \\
\text { chemotherapy }\end{array}$} & \multicolumn{2}{|c|}{$\begin{array}{l}\text { Concurrent radio- } \\
\text { chemotherapy }\end{array}$} & \multirow{2}{*}{$\begin{array}{c}\text { chi }^{2} \\
\text { test }\end{array}$} \\
\hline & & $\mathbf{N}$ & $\%$ & $\mathbf{N}$ & $\%$ & $\mathbf{N}$ & $\%$ & $\mathbf{N}$ & $\%$ & \\
\hline \multirow{3}{*}{$\begin{array}{l}\text { Time of treatment from } \\
\text { radiochemotherapy to end } \\
\text { of radiotherapy }\end{array}$} & \multicolumn{10}{|c|}{ range: $15-208$ days; median 47.5 days } \\
\hline & $\leq 47.5$ & 46 & 50 & 26 & 93 & 0 & 0 & 20 & 77 & \multirow{2}{*}{$<0.001$} \\
\hline & $>47.5$ & 46 & 50 & 2 & 7 & 38 & 100 & 6 & 23 & \\
\hline
\end{tabular}

*p-value - comparison of the percentages between subgroups: right and left tumor localization

$\wedge$-value - comparison of the percentages between subgroups: planoepitheliale and adenocarcinoma type of histopathology

mance status (PS) according to the WHO/ECOG classification during the first visit between patients treated with concurrent radiochemotherapy (no one with PS 2) vs. sequential radiochemotherapy (10\% of patients with PS 2) or radiotherapy alone (14\% of patients with PS 2) ( $p=0.02)$. Patients who underwent a different type of treatment significantly differed in terms of characteristics: clinical stage, lymph node status, PET examination and the time of treatment from radiochemotherapy to the end of radiotherapy (tab. I).

The 2-year overall survival for all patients was 36\%. The median OS ( $\mathrm{mOS}$ ) was 1.5 years ( $95 \%$ confidence interval (Cl): 0.7-2.8 years; (fig. 1). 31 deaths (34\%) were observed during the first year, including 13 patients treated with radiotherapy alone, 9 with sequential radiochemotherapy and 9 with concurrent radiochemotherapy. Patients who underwent radiotherapy alone had a statistically significant worse 2-year OS (25\%; mOS 1.1 years [95\% Cl: 0.5-1.9 years]) in comparison with patients treated with concurrent (46\%; mOS 1.1 years [95\% Cl: $0.5-$ not reached]; $p=0.05)$ and sequential radiochemotherapy (37\%; mOS 1.7 years [95\% Cl: 1.0-2.6 years]; $p=0.03$ ). There was no significant difference observed between concurrent and sequential radiochemotherapy ( $p=0.54$ ) (fig. 2, tab. II). Patients with PS 0-1 during the first consultation had a significantly better mOS -1.6 years $(95 \%$ Cl: 0.7-3.5 years) than patients with PS 2 - mOS 0.7 years ( $95 \%$ Cl: 0.4-1.1 years; $p=0.04$ ) (fig. 3, tab. II). Total treatment time, age, sex, BMI, place of residence, the distance from the place of residence to the Nu-Med Center, lymph node metastasis, tumour localisation, type of histopathology, clinical stage, PET examination had no impact on OS (tab. II).

Table II. Overall survival of patients

\begin{tabular}{|c|c|c|c|c|c|}
\hline & & 2-year OS (\%) & \multicolumn{2}{|c|}{ Median OS [years] $(95 \% \mathrm{Cl})$} & $\begin{array}{c}\text { Log-Rank test } \\
\mathrm{p}\end{array}$ \\
\hline \multicolumn{2}{|c|}{ All } & 36 & 1.5 & $(0.7-2.8)$ & \\
\hline \multicolumn{6}{|c|}{ Age (at start of radiotherapy) } \\
\hline & $\leq 64$ years & 39 & 1.6 & $(0.7-4.2)$ & \multirow{2}{*}{0.17} \\
\hline & $>64$ years & 33 & 1.5 & $(0.6-2.2)$ & \\
\hline \multicolumn{6}{|c|}{ Sex } \\
\hline & women & 50 & 1.6 & $(0.7-2.9)$ & \multirow{2}{*}{0.42} \\
\hline & men & 32 & 1.5 & $(0.6-2.2)$ & \\
\hline \multicolumn{6}{|c|}{ BMI } \\
\hline & $\leq 26$ & 36 & 1.5 & $(0.5-2.3)$ & \multirow{2}{*}{0.76} \\
\hline & $>26$ & 36 & 1.6 & $(0.9-3.2)$ & \\
\hline \multicolumn{6}{|c|}{ Place of residence } \\
\hline & village & 39 & 1.5 & (0.7-not reached) & \multirow{3}{*}{0.72} \\
\hline & cities $\leq 100$ thous & 32 & 1.5 & $(0.7-2.3)$ & \\
\hline & cities $>100$ thous & 41 & 1.6 & $(0.2-3.7)$ & \\
\hline \multicolumn{6}{|c|}{ The distance from place of residence to Nu-Med Center } \\
\hline & $\leq 67 \mathrm{~km}$ & 30 & 1.5 & $(0.5-2.2)$ & \multirow{2}{*}{0.29} \\
\hline & $>67 \mathrm{~km}$ & 42 & 1.6 & $(0.9-3.1)$ & \\
\hline
\end{tabular}


Performance status according to WHO/ECOG scale during first visit

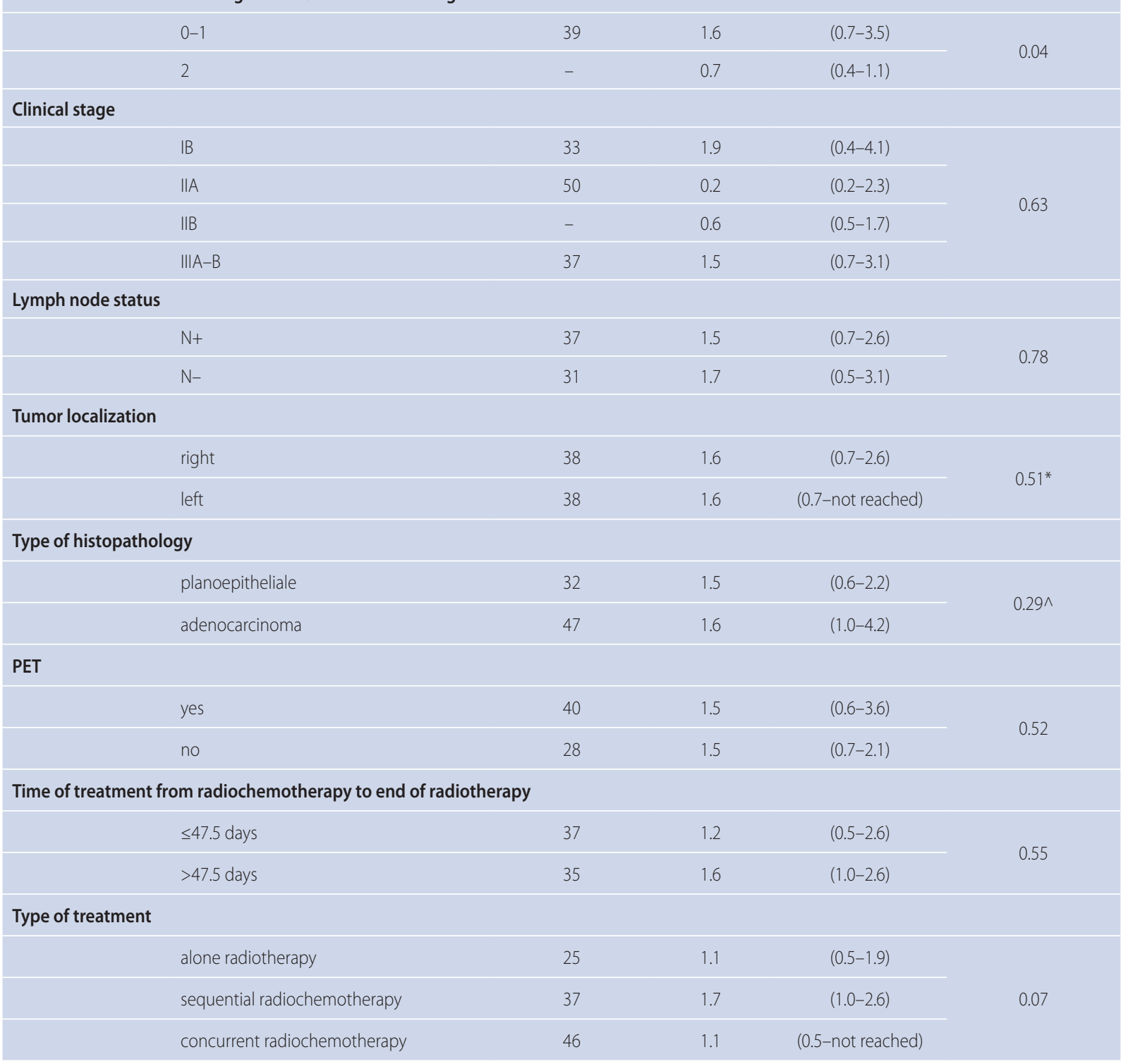

* patients with mediastinum tumor localization were excluded from the analysis

$\wedge$ patients with undetermined type of histopathology were excluded from the analysis

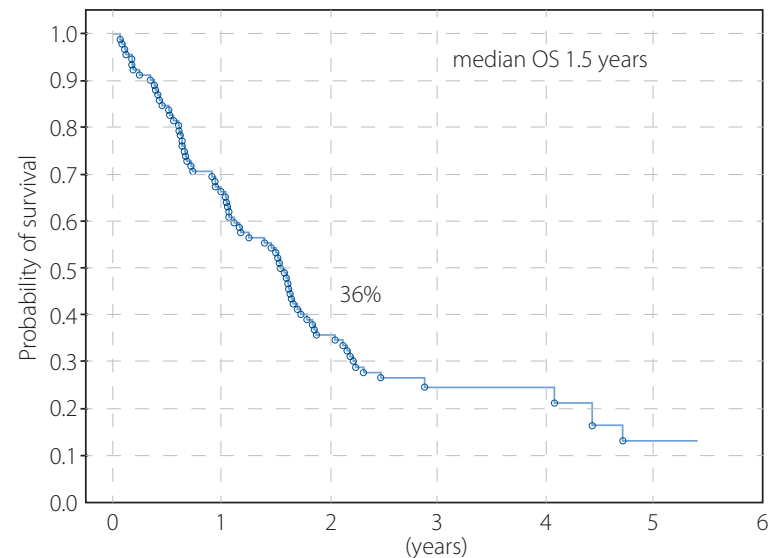

Figure 1. Overall survival for all patients

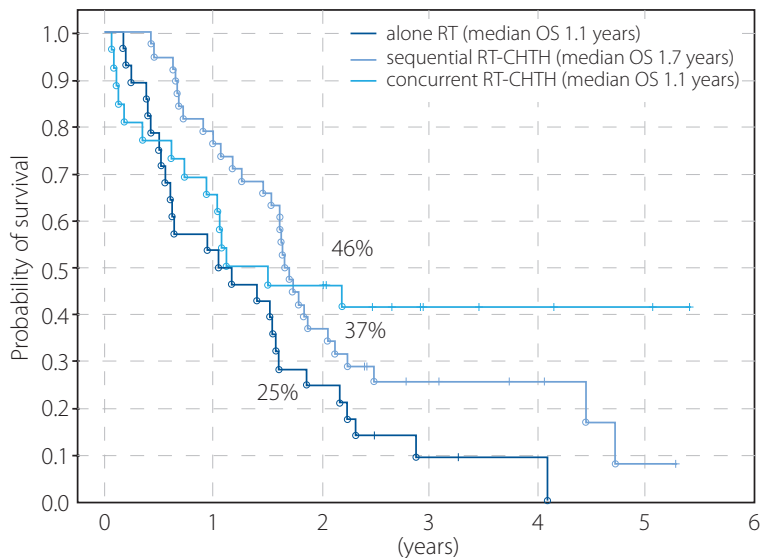

Figure 2. Overall survival by type of treatment 


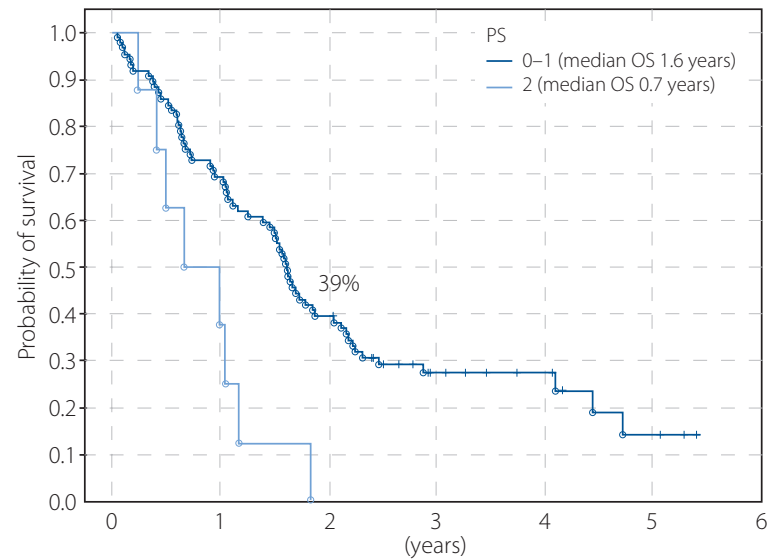

Figure 3. Overall survival by performance status during the first visit

In univariate analysis, only three factors met the inclusion criteria to a multivariate regression model $(p<0.25)$. In multivariate analysis, it was determined that performance status and type of treatment were independent factors influencing OS. The risk of death in patients with WHO/ECOG grade 2 increased by three times (PS 0-1 vs. 2, HR: 3.0; 95\% Cl: 1.4-6.6; $\mathrm{p}=0.006$ ). Increased risk of death was observed in patients treated with radiotherapy alone (HR: $2.4 ; 95 \% \mathrm{Cl}: 1.0-5.6 ; \mathrm{p}=0.04$ ) compared with concurrent radiochemotherapy (tab. III).

\section{Discussion}

The optimal management of NSCLC patients depends on multiple factors, including the clinical stage of the disease, the potential to achieve a complete resection, the patient's overall condition, comorbidities and preferences. The main option for CS I-IIIA (N0-1) NSCLC remains surgery, for clinical stages: IIIA (N2), IIIB, and unresectable I-IIIA (N0-1) the standard of care is radiochemotherapy [10].

The current analysis concerned patients qualified for treatment before and after the Polish National Program of Diagnosis and Treatment of Oncological Diseases was set. Before 2015, in our centre, the decision to use the appropriate treatment was made by a team of radiation oncologists, after disqualification from surgery by thoracic surgeons. In 2015, we started to present patients at a multidisciplinary board with a radiation oncologist, a medical oncologist, a radiologist and a thoracic surgeon, where an accurate treatment plan was chosen.

Curative radiotherapy alone was chosen for elders and patients with a poorer performance status, who had con-

Table III. Uni- and multivariate survival analysis by Cox regression model

\begin{tabular}{|c|c|c|c|c|c|c|}
\hline & \multicolumn{2}{|c|}{ Univariate analysis } & \multicolumn{4}{|c|}{ Multivariate analysis } \\
\hline Variables & \multicolumn{2}{|c|}{$\mathrm{HR}(95 \% \mathrm{Cl})$} & \multirow[t]{2}{*}{$p$} & \multicolumn{2}{|c|}{$\mathrm{HR}(95 \% \mathrm{Cl})$} & \multirow[t]{2}{*}{ p } \\
\hline Age (start of radiotherapy) & & & & & & \\
\hline$\leq 64$ years & 1.0 & reference & & 1.0 & reference & \\
\hline$>64$ years & 1.4 & $(0.9-2.2)$ & 0.17 & 0.79 & $(0.4-1.6)$ & 0.50 \\
\hline \multicolumn{7}{|l|}{ Sex } \\
\hline women & 1.0 & reference & & & & \\
\hline men & 1.3 & $(0.7-2.3)$ & 0.43 & & & \\
\hline \multicolumn{7}{|l|}{ BMI } \\
\hline$\leq 26$ & 1.0 & reference & & & & \\
\hline$>26$ & 0.9 & $(0.6-1.5)$ & 0.76 & & & \\
\hline \multicolumn{7}{|l|}{ Place of residence } \\
\hline village & 1.0 & reference & & & & \\
\hline cities $\leq 100$ thous & 1.2 & $(0.7-2.0)$ & 0.59 & & & \\
\hline cities $>100$ thous & 1.1 & $(0.6-2.2)$ & 0.97 & & & \\
\hline \multicolumn{7}{|c|}{ Distance from place of residence to Nu-Med Center } \\
\hline$>67 \mathrm{~km}$ & 1.0 & reference & & & & \\
\hline$\leq 67 \mathrm{~km}$ & 1.3 & $(0.8-2.1)$ & 0.30 & & & \\
\hline \multicolumn{7}{|c|}{ Performance status according to WHO/ECOG scale during first visit } \\
\hline $0-1$ & 1.0 & reference & & 1.0 & reference & \\
\hline 2 & 2.9 & $(1.4-6.3)$ & 0.006 & 3.0 & $(1.4-6.6)$ & 0.006 \\
\hline
\end{tabular}




\section{Clinical stage}

\begin{tabular}{|lcccc}
\hline IB & 1.0 & reference & \\
\hline IIA & 1.3 & $(0.2-7.9)$ & 0.77 \\
\hline IIB & 2.1 & $(0.4-10.4)$ & 0.38 \\
\hline IIA-B & 0.8 & $(0.3-2.7)$ & 0.76 \\
\hline
\end{tabular}

\section{Lymph nodes}

status

\begin{tabular}{|ccccc}
\hline $\mathrm{N}-$ & 1.0 & reference & \\
\hline $\mathrm{N}+$ & 1.1 & $(0.6-2.2)$ & 0.78
\end{tabular}

\section{Tumor localization}

\begin{tabular}{|ccccc}
\hline left & 1.0 & reference & \\
\hline right & 1.2 & $(0.7-2.0)$ & $0.51^{*}$ \\
\hline
\end{tabular}

\section{Type of histopathology}

$\begin{array}{lccc}\text { adenocarcinoma } & 1.0 & \text { reference } & \\ \text { planoepitheliale } & 1.4 & (0.7-2.4) & 0.32 \wedge\end{array}$

PET

$\begin{array}{lccc}\text { yes } & 1.0 & \text { reference } & \\ \text { no } & 1.2 & (0.7-1.9) & 0.51\end{array}$

Time of treatment from radiochemotherapy to end of radiotherapy

\begin{tabular}{|c|c|c|c|c|c|c|c|}
\hline & $>47.5$ days & 1.0 & reference & & & & \\
\hline & $\leq 47.5$ days & 1.2 & $(0.7-1.8)$ & 0.55 & & & \\
\hline \multicolumn{8}{|l|}{ Type of treatment } \\
\hline & concurrent radiochemotherapy & & & & 1.0 & reference & \\
\hline & alone radiotherapy & 2.1 & $(1.1-4.1)$ & 0.02 & 2.4 & $(1.0-5.6)$ & 0.04 \\
\hline & sequential radiochemotherapy & 1.2 & $(0.7-2.3)$ & 0.53 & 1.1 & $(0.6-2.1)$ & 0.72 \\
\hline
\end{tabular}

* patients with mediastinum tumor localization were excluded from the analysis

$\wedge$ patients with undetermined type of histopathology were excluded from the analysis

traindications to chemotherapy or in whom the application of the combined treatment would significantly increase its toxicity. The 2-year overall survival of our patients treated with radiotherapy only was $25 \%$ and this was at the upper limit of the survival time reported in the literature: 5-28\% [11-15].

Patients in good general condition without significant comorbidities were qualified for combined therapies. At multidisciplinary meetings, concurrent radiochemotherapy was the preferred option. Sequential treatment was selected when the baseline tumour volume excluded radical radiotherapy and chemotherapy would provide a chance to reduce tumour mass (more advanced clinical stage, positive lymph node status).

The addition of chemotherapy to radiation has been the subject of many trials and several meta-analyses. Firstly, its beneficial influence on survival was demonstrated in the case of sequential radiochemotherapy in comparison with radical radiation alone. Adding induction chemotherapy to radiotherapy increased overall survival to $26-31 \%$ at two years [14, 16-18]. Secondly, the introduction of concurrent radiochemotherapy: although this intensification of treatment is associated with higher toxicity, most trials showed better survival with a concurrent association in comparison with sequential therapy $[17,19-24]$. Combining chemotherapy and radiotherapy simultaneously increases 2-year overall survival to 35.6-55.6\% $[8,17,18,23]$.

Our study showed the significant advantage of radiochemotherapy in survival outcomes when compared with radiotherapy alone. The 2-year survival of NSCLC patients treated with sequential and concomitant radiochemotherapy was $37 \%$ and $46 \%$ respectively. The results were comparable to those published in clinical trials and meta-analyses. However, this raport did not manage to show a significant difference in 
efficiency between sequential and concomitant therapy. This could be limited by the small size of the subgroups compared. Unfortunately, our center, especially in the first years of operation, had no impact on the choice of combination therapy (simultaneous vs. sequential). The majority of patients who were suitable for concurrent treatment were referred to our department with no initial PET-CT scan and after the administration of induction chemotherapy - without the decision of a multidisciplinary board.

In the multivariate analysis, the type of treatment and performance status were independent factors influencing OS. We estimated the statistically significant increasing risk of death in patients treated with radiotherapy alone in comparison with concurrent radiochemotherapy and in patients with WHO/ECOG grade 2 at the first consultation. Polish colleagues also confirmed that performance status had a significant association with overall survival [25]. In our analyses, four PS 2 patients were treated with sequential chemoradiotherapy, and their ECOG status was probably an effect of the extent of the disease and chemotherapy toxicity.

In Poland, apart from clinical trias, institutional reports on the effectiveness of oncologic treatment of lung cancer are still lacking. A similar type of institutional report with a survival analysis of NSCLC patients was noted in the case of patients treated in the Warmia and Mazuria Oncology Center in Olsztyn, Poland. The authors showed treatment results for 130 patients treated with chemoradiotherapy in CS IIIA-IIIB and the 2-year overall survival was 37\% [25]. The results are consistent with those reported by our analysis.

Nonetheless, we are aware of the limitations of this study. It is a retrospective analysis, with a small sample and a short observation time. Comparison of the groups also has limited value because of the small subgroups and potential selection bias.

\section{Conclusions}

The survival data of NSCLC patients treated in the Nu-Med Radiotherapy Center in Elblag is comparable to those published in other papers. Forty-six percent of patients treated with concurrent radiochemotherapy survived 2 years. The main risk factors which decreased OS were: the type of therapy and performance status. A significantly worse prognosis was noted in the case of radiation alone compared to radiochemotherapy. and poorer performance status during first consultation. Particular attention should be paid to the proper qualification of the lung cancer patient for the appropriate treatment - preferebly during multidisciplinary meetings.

Conflict of interest: none declared

\author{
Marcin Kurowicki \\ Nu-Med Radiotherapy Center \\ ul Królewiecka 146 \\ 82-300 Elbląg, Poland \\ e-mail:marcin.kurowicki@nu-med.pl
}

Received: 6 Feb 2020

Accepted: 24 May 2020

\section{References}

1. Krajowy Rejestr Nowotworów - Nowotwory złośliwe opłucnej i płuca (C33-34). http://onkologia.org.pl/nowotwory-zlosliwe-oplucnej-pluca-c33-34/.

2. Alberg AJ, Brock MV, Ford JG, et al. Epidemiology of lung cancer: Diagnosis and management of lung cancer, 3rd ed: American College of Chest Physicians evidence-based clinical practice guidelines. Chest. 2013; 143(5 Suppl): e1S-e29S, doi: 10.1378/chest.12-2345, indexed in Pubmed: 23649439.

3. Moura MA, Bergmann A, Aguiar SS, et al. The magnitude of the association between smoking and the risk of developing cancer in Brazil: a multicenter study. BMJ Open. 2014; 4(2): e003736, doi: 10.1136/ bmjopen-2013-003736, indexed in Pubmed: 24519874.

4. Ginsberg JR. Thoracic surgery. Churchill-Livingstone, Philadelphia 2002.

5. EUROCARE - Survival of cancer patients in Europe. https://w3.iss.it/site/ EU5Results/forms/SA0007.aspx.

6. Krzakowski M, Jassem J, Dziadziuszko R. et al. Nowotwory płuca i opłucnej oraz śródpiersia. 20013: 71.

7. Yang P, Allen MS, Aubry MC, et al. Clinical features of 5,628 primary lung cancer patients: experience at Mayo Clinic from 1997 to 2003. Chest. 2005; 128(1): 452-462, doi: 10.1378/chest.128.1.452, indexed in Pubmed: 16002972.

8. Gray JE, Villegas A, Daniel D, et al. PACIFIC Investigators. Overall Survival with Durvalumab after Chemoradiotherapy in Stage III NSCLC. N Engl J Med. 2018;379(24): 2342-2350, doi: 10.1056/NEJMoa1809697, indexed in Pubmed: 30280658.

9. Feinstein AR, Sosin DM, Wells CK. The Will Rogers phenomenon. Stage migration and new diagnostic techniques as a source of misleading statistics for survival in cancer. N Engl J Med. 1985; 312(25): 1604-1608, doi: 10.1056/NEJM198506203122504, indexed in Pubmed: 4000199.

10. Eberhardt WEE, De Ruysscher D, Weder W, et al. Panel Members. 2nd ESMO Consensus Conference in Lung Cancer: locally advanced stage III non-small-cell lung cancer. Ann Oncol. 2015; 26(8): 1573-1588, doi: 10.1093/annonc/mdv187, indexed in Pubmed: 25897013.

11. Blanke CD, Johnson DH. Combined modality therapy in non-small cell lung cancer. Curr Opin Oncol. 1995; 7(2): 144-149, doi: 10.1097/00001622-199503000-00009, indexed in Pubmed: 7756379.

12. Cakir S, Egehan I. A randomised clinical trial of radiotherapy plus cisplatin versus radiotherapy alone in stage III non-small cell lung cancer. Lung Cancer. 2004; 43(3): 309-316, doi: 10.1016/j.lungcan.2003.09.009, indexed in Pubmed: 15165089.

13. Groen HJM, van der Leest AHW, Fokkema E, et al. Continuously infused carboplatin used as radiosensitizer in locally unresectable non-small-cell lung cancer: a multicenter phase III study. Ann Oncol. 2004; 15(3): 427-432, doi: 10.1093/annonc/mdh100, indexed in Pubmed: 14998844

14. Dillman RO, Seagren SL, Propert KJ, et al. A randomized trial of induction chemotherapy plus high-dose radiation versus radiation alone in stage III non-small-cell lung cancer. N Engl J Med. 1990; 323(14): 940-945, doi: 10.1056/NEJM199010043231403, indexed in Pubmed: 2169587.

15. O'Rourke N, Roqué I Figuls $M$, Farré Bernadó N, et al. Concurrent chemoradiotherapy in non-small cell lung cancer. Cochrane Database Syst Rev. 2010(6): CD002140, doi: 10.1002/14651858.CD002140.pub3, indexed in Pubmed: 20556756.

16. Huber RM, Flentje M, Schmidt M, et al. Bronchial Carcinoma Therapy Group. Simultaneous chemoradiotherapy compared with radiotherapy alone after induction chemotherapy in inoperable stage IIIA or IIIB non-small-cell lung cancer: study CTRT99/97 by the Bronchial Carcinoma Therapy Group. J Clin Oncol. 2006; 24(27): 4397-4404, doi: 10.1200/ JCO.2005.05.4163, indexed in Pubmed: 16983107.

17. Curran WJ, Paulus R, Langer CJ, et al. Sequential vs. concurrent chemoradiation for stage III non-small cell lung cancer: randomized phase III trial RTOG 9410. J Natl Cancer Inst. 2011; 103(19): 1452-1460, doi: 10.1093/jnci/djr325, indexed in Pubmed: 21903745.

18. Aupérin A, Le Péchoux C, Rolland E, et al. Meta-analysis of concomitant versus sequential radiochemotherapy in locally advanced non-small-cell lung cancer. J Clin Oncol. 2010; 28(13): 2181-2190, doi: 10.1200/ JCO.2009.26.2543, indexed in Pubmed: 20351327.

19. Belani CP, Wang W, Johnson DH, et al. Eastern Cooperative Oncology Group. Phase III study of the Eastern Cooperative Oncology Group (ECOG 2597): induction chemotherapy followed by either standard thoracic radiotherapy or hyperfractionated accelerated radiotherapy for patients with unresectable stage IIIA and B non-small-cell lung cancer. 
J Clin Oncol. 2005; 23(16): 3760-3767, doi: 10.1200/JCO.2005.09.108, indexed in Pubmed: 15837967.

20. Provencio M, Isla D, Sánchez A, et al. Inoperable stage III non-small cell lung cancer: Current treatment and role of vinorelbine. J Thorac Dis. 2011;3(3): 197-204, doi: 10.3978/j.issn.2072-1439.2011.01.02, indexed in Pubmed: 22263088.

21. Gouda YS, Kohail HM, Eldeeb NA, et al. Randomized study of concurrent carboplatin, paclitaxel, and radiotherapy with or without prior induction chemotherapy in patients with locally advanced non-small cell lung cancer. J Egypt Natl Canc Inst. 2006; 18(1): 73-81, indexed in Pubmed: 17237853.

22. Jalal SI, Riggs HD, Melnyk A, et al. Hoosier Oncology Group, US Oncology. Phase III study of cisplatin, etoposide, and concurrent chest radiation with or without consolidation docetaxel in patients with inoperable stage III non-small-cell lung cancer: the Hoosier Oncology Group and U.S. Oncology. J Clin Oncol. 2008; 26(35): 5755-5760, doi: 10.1200/ JCO.2008.17.7840, indexed in Pubmed: 19001323.
23. Bradley JD, Paulus R, Komaki R, et al. Standard-dose versus high-dose conformal radiotherapy with concurrent and consolidation carboplatin plus paclitaxel with or without cetuximab for patients with stage IIIA or IIIB non-small-cell lung cancer (RTOG 0617): a randomised, two-by-two factorial phase 3 study. Lancet Oncol. 2015; 16(2): 187-199, doi: 10.1016/S1470-2045(14)71207-0, indexed in Pubmed: 25601342.

24. Walraven I, Damhuis RA, Ten Berge MG, et al. Treatment Variation of Sequential versus Concurrent Chemoradiotherapy in Stage III Non-Small Cell Lung Cancer Patients in the Netherlands and Belgium. Clin Oncol ( $R$ Coll Radiol). 2017; 29(11): e177-e185, doi: 10.1016/j.clon.2017.07.012, indexed in Pubmed: 28780009.

25. Osowiecka K, Rucińska M, Każarnowicz A, et al. Przeżycia chorych na niedrobnokomórkowego raka płuca leczonych napromienianiem w latach 2003-2006 w Samodzielnym Publicznym Zakładzie Opieki Zdrowotnej Ministerstwa Spraw Wewnętrznych z Warmińsko-Mazurskim Centrum Onkologii w Olsztynie. NOWOTWORY J Oncol. 2015; 65(1): 14-22, doi: 10.5603/njo.2015.0003 